\title{
Analisis Pendapatan Nelayan Perahu Motor Tempel dan Perahu Motor Lampara di Kelurahan Humusu C Kecamatan Insana Utara
}

Rofinus A. Suri ${ }^{\mathrm{a}}$, dan Simon Juan Kune ${ }^{\mathrm{b}}$

${ }^{a}$ Fakultas Pertanian, Universitas Timor, Kefamenanu, TTU - NTT, Indonesia.

${ }^{b}$ Fakultas Pertanian, Universitas Timor, Kefamenanu, TTU - NTT, Indonesia.

\section{Article Info}

Article history:

Received 7 April 2017

Received in revised form 20 April 2017

Accepted 7 Juni 2017

\section{Keywords:}

Pendapatan

Nelayan

Perahu Motor Tempel

Perahu Motor Lampara

Humusu C

\section{Abstrak}

Sumberdaya ikan bersifat terbuka untuk dimanfaatkan oleh siapa saja dan dikategorikan sebagai sumberdaya yang dapat pulih. Kelurahan Humusu C, merupakan salah satu kelurahan yang berada di kecamatan Insana Utara, Kabupaten Timor Tengah Utara yang wilayahnya berada di pesisir pantai dengan sebagian masyarakat memilih untuk bermata pencaharian sebagai nelayan. Penelitian ini bertujuan adalah untuk mengetahui 1) gambaran umum nelayan perahu motor Tempel dan perahu motor Lampara; dan 2) besar pendapatan yang diperoleh nelayan perahu motor Tempel dan perahu motor Lampara di kelurahan Humusu C kecamatan Insana Utara yang dilakukan pada bulan Desember 2015 sampai Januari 2017. Untuk mengetahui gambaran umum usaha tangkapan ikan maka digunakan analisis deskriptif kualitatif sedangkan untuk mengetahui pendapatan nelayan dilakukan analisis pendapatan. Hasil penelitian menunjukkan bahwa usaha penangkapan ikan yang dilakukan oleh nelayan dengan menggunakan perahu motor Tempel dan perahu motor Lampara. Perahu motor Tempel menggunakan alat tangkap dengan memakai pukat $1 / 4$ Ins, pukat 1 Ins, pukat 2 Ins, dan pancing dengan ukuran yang berbedabeda antara lain motor kecil 5,5 PK, yang beroperasi di siang hari dan motor besar 9-28 PK. Rata-rata pendapatan perahu motor Tempel adalah Rp. 29.145.845 dengan pendapatan tertinggi Rp. 42.085.455 dan pendapatan terendah Rp. 12.402.455. Sedangkan usaha penangkapan ikan yang menggunakan perahu motor Lampara dengan memakai pukat Lampara dan pancing, yang beroperasi pada malam hari dengan ukuran motor Tempel 17 x 3 m dengan kekuatan 300 PK. Rata-rata pendapatan perahu motor Lampara adalah Rp. 81.061 .600 dengan pendapatan tertinggi Rp. 95.402 .643 dan pendapatan terendah Rp. 72.213.883. (O2017 dipublikasikan oleh Agrimor.

\section{Pendahuluan}

Sumberdaya ikan bersifat terbuka untuk dimanfaatkan oleh siapa saja dan dikategorikan sebagai sumberdaya yang dapat pulih, namun seringkali muncul pertanyaan seberapa besarkah sumberdaya yang dapat dimanfaatkan tanpa harus menimbulkan dampak negatif dikemudian hari. Keberlanjutan menjadi kata kunci dalam pembangunan perikanan yang diharapkan dapat memperbaiki kondisi sumberdaya serta kesejahteraan masyarakat perikanan (Fauzi \& Anna, 2005)

Kelurahan Humusu C, merupakan salah satu kelurahan yang berada di kecamatan Insana Utara, Kabupaten Timor Tengah Utara (TTU) yang wilayahnya berada di pesisir pantai. Karena wilayahnya berada di pesisir pantai maka sebagian masyarakat memilih untuk bermata pencaharian sebagai nelayan yakni nelayan penuh sebanyak $58 \mathrm{KK}$, nelayan sambilan utama sebanyak 154 KK dan sambilan tambahan sebanyak 16 KK. Hasil tangkapan ikan oleh nelayan dimanfaatkan untuk dijual secara langsung dan dikonsumsi. Selain itu, terdapat juga ikan hasil tangkapan yang diolah menjadi produk tertentu baru kemudian dipasarkan. Kobesi \& Hutapea, (2016) melaporkan bahwa usaha pengolahan abon ikan di Kelurahan Humusu C mempunyai prospek pengembangan sanga menjanjikan. Kaet \& Hutapea, (2016) yang melakukan analisis finasial pada usaha tersebut juga menyatakan usaha abon ikan pada kelompok pengolahan ikan Pantura layak dilaksanakan berdasarkan nilai Net B/C Ratio dan nilai NPV.

Pemanfaatan sumberdaya perikanan di kelurahan Humusu C, masih didominasi oleh usaha perikanan rakyat ini umumnya memiliki karakteristik usaha skala kecil hingga menengah, teknologi sederhana, jangkauan daerah penangkapan yang terbatas, serta produktivitas yang relatif masih rendah. Umumnya nelayan di wilayah ini menggunakan perahu motor Tempel dan perahu motor Lampara. Menurut Barus et al., (1991), produktivitas nelayan yang rendah umumnya diakibatkan oleh rendahnya keterampilan dan pengetahuan serta penggunaan alat penangkapan maupun perahu yang masih sederhana sehingga efektifitas dan efisiensi alat tangkap dan penggunaan faktor-faktor produksi lainnya belum optimal.

Sasaran akhir dari suatu kegiatan usaha perikanan oleh masyarakat bukan hanya pada produksi, tetapi juga keuntungan. Produksi yang tinggi diharapkan akan meningkatkan keuntungan serta memungkinkan stabilitas usaha dapa dipertahankan sekaligus dapat mengupayakan pengembangannya. Sebagian besar hasil tangkapan ikan langsung dipasarkan saat nelayan merapat di pantai. Selanjutnya menurut Selan \& Nubatonis, (2016) terdapat lima saluran pemasaran yang terjadi hingga ikan sampai pada konsumen dengan margin pemasaran yang berbeda-beda dalam setiap salurannya. Pada tingkat pedagang pengecer di Kefamenanu, Hutapea, (2016) melaporkan bahwa pendapatan harian pedagang ikan secara umum bersifat fluktuatif berkisar antara Rp. 50.000 - Rp. 300.000 dengan faktor yang berpengaruh nyata adalah modal dan jumlah jam kerja.

Dari berbagai uraian di atas, muncul pertanyaan tentang seberapa besar pendapan dari nelayan itu sendiri yang telah memberikan kontribusi terhadap pergerakan perekonomian di kabupaten TTU. Prinsip biologi dan teknologi memegang peranan penting dalam pengembangan perikanan, tetapi keberhasilan dan keberlangsungan dari usaha perikanan tersebut juga bergantung pada prinsip-prinsip ekonomi/finansial, untuk itu perlu dilakukan kajian tentang "Analisis Pendapatan Nelayan Perahu Motor Tempel dan Perahu Motor Lampara di Kelurahan Humusu C Kecamatan Insana Utara”. Tujuan penelitian ini adalah untuk mengetahui 1) gambaran umum nelayan perahu motor Tempel dan perahu motor Lampara; dan 2) besar pendapatan yang diperoleh nelayan perahu moto Tempel dan perahu motor Lampara di kelurahan Humusu C kecamatan Insana Utara.

\section{Metode}

Penelitian dilaksanakan di Kelurahan Humusu C, Kecamatan Insana Utara, Kabupaten TTU, pada bulan Desember 2015 sampai Januari 2017. Pengumpulan data dilakukan dengan metode survei. Teknik pengambilan sampel dalam penelitian ini menggunakan teknik simple random sampling yaitu pengambilan sampel secara acak dimana setiap elemen dari populasinya mempunyai peluang yang sama-sama besar untuk terpilih ke dalam sampel. Teknik pengambilan dan penetapan jumlah sampel penelitian dilakukan dengan cara menggunakan rumus slovin sesuai petunjuk Ating \& Sambas, (2006) sehingga jumlah sampel yang digunakan adalah sebanyak 49 responden.

Dimana data yang dikumpulkan berupa data primer dan data sekunder. Data primer adalah data-data yang diperoleh melalui wawancara dengan responden berdasarkan daftar pertanyaan yang disiapkan sebelumnya, sedangkan data sekunder adalah data yang diperoleh instansi terkait.

Data yang diperoleh dikumpulkan kemudian ditabulasi dan dianalisis berdasarkan tujuan penelitian. Untuk menjawab tujuan pertama yaitu mengetahui gambaran umum usaha tangkapan ikan peneliti menggunakan metode analisis deskriptif kualitatif sesuai petunjuk Sugiyono, (2006). Untuk menjawab tujuan kedua dilakukan analisis pendapatan sesuai petunjuk Djamin, (1984).

\section{Hasil dan Pembahasan}

\subsection{Gambaran Umum Usaha Penangkapan Ikan}

Usaha penangkapan ikan yang dilakukan oleh nelayan di Kelurahan Humusu $\mathrm{C}$ menggunakan alat tangkap perahu motor Tempel dengan memakai pukat $1 / 4$ Ins, pukat $1 \mathrm{Ins}$, pukat $2 \mathrm{Ins}$, dan pancing dengan ukuran yang berbeda antara lain motor kecil 5,5 PK, yang beroperasi pada siang hari dan motor besar 9-28 PK yang beroperasi pada malam hari. Perahu motor yang beroperasi pada siang hari memiliki ukuran $6 \times 1 \mathrm{~m}$, sedangkan perahu yang beroperasi pada malam hari berukuran $12 \times 2 \mathrm{~m}$.

Usaha penangkapan ikan yang menggunakan perahu motor Lampara memakai pukat Lampara dan pancing, yang beroperasi pada malam hari dengan ukuran 17 x 3 m dengan kekuatan 300 PK. Cara penangkapan ikan dengan motor Lampara adalah melingkari gerombolan ikan dengan jaring, sehingga jaring tersebut membentuk dinding vertikal, dengan demikian gerakan ikan ke arah horizontal dapat dihalang.

\subsection{Penggunaan Tenaga Kerja}

Tenaga kerja merupakan faktor yang sangat penting dalam produksi, karena tenaga kerja merupakan faktor penggerak faktor input yang lain. Tanpa adanya tenaga kerja maka faktor produksi lain tidak akan berarti. Secara keseluruhan rata-rata penggunaan curahan tenaga kerja perahu motor Tempel untuk penangkapan ikan di Kelurahan Humusu C pada musim 2016 adalah sebesar 617,8 HKO degan kisaran curahan tenaga kerja 596-648 HKO. Sedangkan ratarata penggunaan curahan tenaga kerja perahu motor Lampara untuk usaha penangkapan ikan di Kelurahan Humusu C pada musim 2016 adalah sebesar 173,47 HKO dengan kisaran curahan tenaga kerja 130-576 HKO.

\subsection{Penggunaan Modal}

Biaya tangkapan perahu motor Tempel dan perahu motor Lampara dalam usaha penangkapan ikan meliputi biaya bahan penolong, biaya penyusutan, dan biaya tenaga kerja. Biaya-biaya tersebut kemudian diuraikan masing-masing sebagai biaya variabel, biaya tetap dan biaya tenaga kerja seperti pada Tabel 1 . Penggunaan biaya tertinggi pada usaha tangkapan ikan dengan perahu motor Tempel maupun perahu motor Lampara adalah biaya tenaga kerja sedangkan biaya terendah adalah biaya variabel. 
Tabel 1. Rata-Rata Biaya Produksi pada Usaha Penangkapan Ikan di Kelurahan Humusu C Tahun 2016.

\begin{tabular}{lcc}
\hline \multirow{2}{*}{ Jenis Biaya } & \multicolumn{2}{c}{ Rata-Rata Biaya (Rp) } \\
\cline { 2 - 3 } & Perahu Motor Tempel & Perahu Motor Lampara \\
\hline Biaya Variabel & 141.664 & 984.511 \\
Biaya Tetap & 1.197 .590 & 9.959 .889 \\
Biaya Tenaga Kerja & 6.905 .000 & 47.474 .000 \\
\hline
\end{tabular}

\subsection{Hasil Tangkapan dan Penerimaan}

Rata-rata tangkapan perahu motor Tempel yaitu ikan tembang sebanyak 24,19 kumbang per bulan, ikan Kombong sebanyak 24,33 kumbang per bulan, ikan Tongkol sebanyak 16,90 kumbang per bulan, ikan Ambulau sebanyak 3,79 kumbang per bulan, ikan ekor kuning sebanyak 6,16 kumbang per bulan dan ikan cakalang sebanyak 7,63 kg per bulan. Penerimaan rata-rata perahu motor Tempel dalam satu bulan adalah Rp. 37.722 .347 dengan penerimaan tertinggi Rp. 59.820.000 dan penerimaan yang terendah adalah Rp. 14.600.000.

Rata-rata tangkapan perahu motor Lampara yaitu ikan tembang sebanyak 62,4 kumbang per bulan, ikan Kombong sebanyak 57 kumbang per bulan, ikan Tongkol sebanyak 54 kumbang per bulan, ikan Ambulau sebanyak 50,2 kumbang per bulan, dan ikan cakalang sebanyak $83 \mathrm{~kg}$ per bulan. Penerimaan rata-rata perahu motor Lampara dalam satu bulan Rp. 139.480.000. dengan penerimaan tertinggi Rp. 153.220.000 dan penerimaan yang terendah adalah Rp. 130.180.000.

\subsection{Pendapatan}

Rata-rata pendapatan perahu motor Tempel setiap responden adalah $\mathrm{Rp}$. 29.145.845 dengan pendapatan perahu motor Tempel tertinggi Rp. 42.085.455 sedangkan pendapatan perahu motor Tempel terendah Rp. 12.402.455. Sedangkan rata-rata pendapatan perahu motor Lampara setiap responden $\mathrm{Rp}$. 81.061.600 dengan pendapatan perahu motor Lampara tertinggi Rp. 95.402.643 dan pendapatan terendah Rp. 72.213.883.

\section{Simpulan}

Usaha penangkapan ikan yang dilakukan oleh nelayan dengan menggunakan perahu motor Tempel dan perahu motor Lampara. Perahu motor Tempel menggunakan alat tangkap dengan memakai pukat 1/4 Ins, pukat 1 Ins, pukat 2 Ins, dan pancing dengan ukuran yang berbeda-beda antara lain motor kecil 5,5 PK, yang beroperasi di siang hari dan motor besar 9-28 PK. Rata-rata pendapatan perahu motor Tempel adalah Rp. 29.145.845 dengan pendapatan tertinggi Rp. 42.085.455 dan pendapatan terendah Rp. 12.402.455. Sedangkan usaha penangkapan ikan yang menggunakan perahu motor Lampara dengan memakai pukat Lampara dan pancing, yang beroperasi pada malam hari dengan ukuran motor Tempel 17 × 3 m dengan kekuatan 300 PK. Rata-rata pendapatan perahu motor Lampara adalah Rp. 81.061 .600 dengan pendapatan tertinggi Rp. 95.402.643 dan pendapatan terendah Rp. 72.213.883.

\section{Pustaka}

Ating, S. \& Sambas, A.M. 2006. Aplikasi Statistika Dalam Penelitian. Bandung: Penerbit Pustaka Setia.

Barus, H.R., Badrudin \& Naamin, N. 1991. Potensi Sumberdaya Perikanan Laut dan Strategi Pemanfaatannya Bagi Pengembangan Perikanan yang Berkelanjutan. Prosiding Forum II Perikanan Sukabumi. Jakarta: Pusat Penelitian dan Pengembangan Pertanian Departemen Pertanian.

Djamin, Z. 1984. Perencanaan dan Analisis Proyek. Jakarta: Lembaga Penerbit Fakultas Ekonomi, Universitas Indonesia.

Fauzi, A. \& Anna, S. 2005. Pemodelan Sumberdaya Perikanan dan Kelautan Untuk Analisis Kebijakan. Jakarta: Gramedia Pustaka Utama.

Hutapea, A.N. 2016. Faktor-Faktor yang Mempengaruhi Pendapatan Harian Pedagang Ikan di Kefamenanu Kabupaten Timor Tengah Utara. AGRIMOR, 1(01): 13-14.

Kaet, L. \& Hutapea, A.N. 2016. Analisis Finansial Usaha Abon Ikan pada Kelompok Pengolahan Ikan Pantura di Kelurahan Humusu C, Kecamatan Insana Utara, Kabupaten Timor Tengah Utara. AGRIMOR, 1(04): 82-83.

Kobesi, P. \& Hutapea, A.N. 2016. Prospek Pengembangan Usaha Abon Ikan di Kelurahan Humusu C, Kecamatan Insana Utara, Kabupaten Timor Tengah Utara. AGRIMOR, 1(02): 21-23.

Selan, D.M. \& Nubatonis, A. 2016. Margin Pemasaran Ikan di Kecamatan Insana Utara Kabupaten Timor Tengah Utara. AGRIMOR, 1(03): 63-64.

Sugiyono 2006. Metode Penelitian Kuantitatif, Kualitatif dan $R \& D$. Bandung: Alfabeta. 